\title{
Dynamics of Enterprises in the Slovenian Textile Industry
}

\author{
BARBARA JERNEJČIČ DOLINAR \\ Faculty of Design, Slovenia \\ barbara.dolinar@siol.net \\ ŠTEFAN BOJNEC \\ University of Primorska, Slovenia \\ stefan.bojnec@fm-kp.si
}

The article deals with the dynamics of reducing the size structure and the number of employees in large and medium-sized textile enterprises, which influence the entry of new micro and small enterprises into the Slovenian textile industry. Before the Slovenian independence in 1991, the Slovenian textile industry was considered to be a strong labour-intensive industry, with 69,454 employees in 1990, while in 2017 it counts only 9,800 employees. In analysing the dynamics of enterprises in the textile industry, we use enterprise accounts data on micro, small, medium and large enterprises in the period from 2006 to 2017. The research contributes to a detailed insight into the restructuring process of the Slovenian textile industry by significantly reducing the number and size of large and medium-sized textile enterprises, which were uncompetitive, rigid, inflexible and time-consuming compared with global manufactures of textile products and exits, and relatively small entry of new micro and small enterprises. The research addresses a narrower scientific field in the textile industry, which is concerned with reducing the size and age of enterprises resulting from the exit of large and medium enterprises in the textile industry and the creation of new micro and small enterprises within the industry.

Key words: dynamics of enterprises, entry of enterprises, exit of enterprises, textile industry, Slovenia

https://doi.org/10.26493/1854-4231.14.185-203

\section{Introduction}

The paper deals with the narrower scientific field of dynamics of reducing the size and age of large and medium-sized textile companies, which influence the entry of new micro and small enterprises into the Slovenian textile industry in the period from 2006 to 2017.

The previous literature and data sources in the field of entry and exit of enterprises, employment and size of enterprises include the 
entire manufacturing industry in Slovenia (Bojnec and Xavier 2004; 2005; 2007; Kocjančič and Bojnec 2010), while there is not available a specific study for the Slovenian textile industry. This has motivated our research, because the textile industry in Slovenia and in the Central and Eastern European (CEE) countries was important during the socialist period.

The research is based on theoretical knowledge and empirical analyzes on the dynamics, restructuring and transformation of the Slovenian enterprises and their survival (Bojnec and Xavier 2004; 2005; 2007; Kocjančič and Bojnec 2010), and enterprises in other countries, particularly emerging market economies (Cincera and Galgau 2005; Geroski, Mata, and Portugal 2003; Kaya and Üçdoğruk 2002; Ghosal 2003; Sönmez 2013; Geroski 1995; Dunne, Roberts, and Samuelson 1989).

The aim of the research is to find out how and to what extent changes in the size structure and age of large and medium-sized textile enterprises affect the dynamics of new micro and small enterprises in the textile industry in response to the drastic decline in the number of large and medium-sized enterprises in the textile industry or restructuring large and medium-sized enterprises. The main thesis of the research is tested with the set of two research hypotheses. The results of the empirical research using secondary data are presented for large, medium, small and micro Slovenian textile enterprises in the period from 2006 to 2017. On this basis in the concluding part of the paper are presented our conclusions and some suggestions.

\section{Theoretical Background}

The entry and exit rates of enterprises vary widely from industry to industry. Enterprises entry and exit is part of the market selection process, by which assets are distributed across industries and promote the introduction of new technologies, which affects economic performance.

Audretsch (1991) found that survival rates vary widely across the industries and they were shaped by conditions of the industry which depend on technology and demand conditions. The dynamic of entry and exit of enterprises from the market is determinant by several factors at the level of the enterprises, industries, and countries. It can also driven by entry and exit barriers and strategies to deter entry and exit of the enterprises from the market.

European Commission (2005) investigated the impact of product market reforms on entry and exit of enterprises. There were found 
two effects: internal restructuring, which refers to the productivity growth of individual enterprise present in the industry, and external restructuring, whereby the market selection procedure leads to a reallocation of resources between enterprises. The change in the entry and exit of the enterprises consequently affects the macroeconomic results.

The analyses of the dynamics of entry and exit of enterprises shows that a large number of enterprises enter and exit the markets every year. The most difficult period for a new enterprise to survive is the early years. About 30 to 40 percent of new entering enterprises do not survive the first two years. The likelihood exit of the new enterprise is highly skewed towards small and micro units, while the surviving enterprises are not only larger but also growing faster (Scarpetta et al., 2002).

Newly established small enterprises are an important driver of innovation and job creation, indispensable for long-term economic growth and economic prosperity (Birch 1979; Carlsson 1999; Haltiwanger, Jarmin, and Miranda 2013). Based on an analysis of the dynamics of newly-established enterprises in the United States, Haltiwanger, Jarmin, and Miranda (2013) found that the newly established enterprises grow faster than mature-older enterprises, whereby newly established enterprises have much more likely of exit rate. In general, the newly established enterprises are more volatile and show higher levels of gross job creation. Small enterprises have a shorter life expectancy, lower productivity, and they pay lower wages and provide less job security than large enterprises. Two main reasons that confirm the important role of small enterprises are efficiency and dynamics, as some small enterprises do some things better than large enterprises (Carlsson 1999).

The research of dynamics of enterprises in the manufacturing sector in Slovenia clearly shown that the volatility of corporate dynamics was greater than the volatility of labour dynamics, except at a very early stage of institutional change with the internal transformation of traditional social enterprises, the corporate entry rates were higher than enterprises exit rates (Bojnec and Xavier, 2005).

Geroski (1995) justified the age of the enterprises with the obtained experience in the market, which may be more important than its size, because older enterprises are less likely to be closed down.

Newly established enterprises were on average smaller, but more dynamic than traditional large enterprises and invest more in new equipment and machinery (Bojnec and Xavier 2004). Moreover, Bojnec and Xavier (2005) noted that most manufacturing industries 
were traditional ones that were considered to be declining in the developed countries, because they often experienced a lower valueadded per employee and/or decreasing demands. They were developed on the basis of local labour (leather, footwear, and textile industry) or they were created during the socialist development, after the Second World War (metal and similar industries).

The research of the dynamics of enterprise entry and survival in Portugal in the period from 2005 to 2012 found that around 41 percent of newly established enterprises survived throughout the sampling period observed, whereby the survival rate did not depent on the enterprise's economic activity sector (Félix 2017).

There is a greater likelihood of survival and higher growth rates for newly established enterprises related to the adaptation and ability to market adjustment with a viable product (Audretsch 1995). Moreover, Audretcsh (1995) argued that the only two traditional structural barriers can impede survival: economies of scale and product differentiation. They are not permanent and weaken when the entrepreneur gains experience in the industry, or at least with the age of an enterprise when the time period after the enterprise's entry increases.

The comparative research conducted by Jelili and Goaied (2009) based on the complete capture of the Tunisian manufacturing sector data from the business registry. The research is based on the calculation of a series of data on the number of entries (newly-established enterprises) and exits and the total number of enterprises with more than 10 employees, by years and industry, in the period from 1996 to 2004. The size of the enterprises was crucial in the analysis of exit rates, for several reasons: first, that smaller enterprises had more potential for expansion and their 'small size' can mean more entry and exit, as well as more growth for successful enterprises after entry. Second, the sector specificity of a given country in newer industries, where mixing is usually larger and more enterprises experiment with different technologies.

On the basis of the literature review, we raised a research question concerning the reduction of the size and age of textile enterprises and the dynamics of entry of new micro and small enterprises and the exit of large and medium-sized textile enterprises in the industry. The main thesis of the research is that the entry of micro and small enterprises into the textile industry is related to the exit and restructuring by reducing the size and age of the existing enterprises in the textile industry and that the survival of enterprises in the textile industry is an indicator of business success. 
The main thesis is tested with the set two hypotheses:

$\mathrm{H} 1$ The entry rate of micro and small textile enterprises increases with the decreases in the number of large and medium-sized textile enterprises and the survival rate of the existing large and medium-sized textile enterprises.

$\mathrm{H} 2$ The exit rate of medium and large textile enterprises decreases as value-added per employee and enterprise performance expressed by the EBITDA indicator increases.

\section{Stylized and Empirical Data Facts}

\section{DYNAMICS OF ENTERPRISES IN THE COUNTRIES OF THE EUROPEAN UNION}

Between the period 2008 and 2017, the gross value added generated by small and medium-sized enterprises (SMES) in the EU-28 increased cumulatively by $14.3 \%$ and employment in the SMES increased by $2.5 \%$. Developments in the EU- 28 member states differed. In the EU-6 member states (Croatia, Cyprus, Greece, Italy, Portugal and Spain), gross value added in the SMES in 2017 was still below that in 2008 levels. In the EU-15 member states Bulgaria, Croatia, Cyprus, Czech Republic, Denmark, France, Greece, Ireland, Italy, Latvia, Lithuania, Portugal, Romania, Slovenia, and Spain) the employment rate in the SMES in 2017 did not reach the level of 2008. In all EU-28 member states, the SMEs have made a significant contribution to the recovery and further expansion of their economies over the period 2008-2017. Their contribution largely exceeded expectations based on their relative importance in the economy. Between 2008 and 2017, the number of the SMES in the EU-28 member increased by $13.8 \%$. The number of newly-established SMEs exceeded the actual increase in the SME population due to the high rate of non-survival of the existing SMES, especially among young enterprises. Each new SME that survived in the period 2012-2015 required nine SMES that did not survive (European Commision 2019).

MICRO AND SMALL INDUSTRIAL ENTERPRISES IN SLOVENIA

The previous research on the corporate sector and entrepreneurial dynamics has largely focused on developed market economies. However, there is a growing interest in exploring entrepreneurship and dynamics of enterprises in emerging market economies, including in Slovenia (Bojnec and Xavier 2004; 2005; 2007; Rebernik, Tominc, and Pušnik 2006; Kocjančič and Bojnec 2010). 
TABLE 1 Dynamics of Newly Established Micro and Small Enterprises in the Slovenian Industry in the Period from 2006 to 2016

\begin{tabular}{lrrrrrrrrrrr}
\hline Year & 2006 & 2007 & 2008 & 2009 & 2010 & 2011 & 2012 & 2013 & 2014 & 2015 & 2016 \\
\hline$(1)$ & 789 & 688 & 873 & 869 & 877 & 960 & 1327 & 1981 & 1310 & 1085 & 1131 \\
$(2)$ & 201 & 249 & 309 & 297 & 309 & 309 & 319 & 314 & 335 & 297 & 293 \\
$(3)$ & 22 & 27 & 24 & 24 & 28 & 28 & 35 & 41 & 48 & 38 & 38 \\
$(4)$ & 12 & 12 & 17 & 3 & 6 & 161 & 22 & 19 & 12 & 17 & 15 \\
\hline$(5)$ & 1024 & 976 & 1223 & 1193 & 1220 & 1313 & 1703 & 2355 & 1705 & 1437 & 1477 \\
\hline
\end{tabular}

Nотеs Row headings are as follows: (1) micro enterprise (o employees), (2) micro enterprise (1-4 employees), (3) micro enterprise (5-9 employees), (4) small enterprise (10+ employees), (5) total number of micro and small enterprises. Based on data from sors (see http://pxweb.stat.si).

TABLE 2 Dynamics of Exit of Micro and Small Enterprises in the Slovenian Industry in the Period from 2006 to 2016

\begin{tabular}{lrrrrrrrrrrr}
\hline Year & 2006 & 2007 & 2008 & 2009 & 2010 & 2011 & 2012 & 2013 & 2014 & 2015 & 2016 \\
\hline$(1)$ & 668 & 565 & 686 & 760 & 861 & 662 & 808 & 910 & 1006 & 1127 & 784 \\
$(2)$ & 225 & 222 & 246 & 283 & 306 & 293 & 332 & 346 & 278 & 271 & 290 \\
$(3)$ & 17 & 10 & 12 & 19 & 22 & 15 & 17 & 17 & 18 & 26 & 27 \\
$(4)$ & 9 & 9 & 13 & 13 & 15 & 9 & 14 & 17 & 11 & 10 & 29 \\
\hline$(5)$ & 919 & 806 & 957 & 1075 & 1204 & 979 & 1171 & 1290 & 1313 & 1434 & 1130 \\
\hline
\end{tabular}

Notes Row headings are as follows: (1) micro enterprise (o employees), (2) micro enterprise (1-4 employees), (3) micro enterprise (5-9 employees), (4) small enterprise (10+ employees), (5) total number of micro and small enterprises. Based on data from sors (see http://pxweb.stat.si).

In 2006, according to the standard activity classification (sAc), the classification for activities from mining (C) to water supply, sewage, and waste management, environmental remediation (E) was 1024 newly established micro and small enterprises with a survival rate of $71.4 \%$ after one year and $77.4 \%$ after two years of operation (table 1 ). In 2007, 976 newly established micro and small enterprise was registered, which increased to 1477 in 2016. As can be seen from table 1 and table 2 , the number of newly established micro and small enterprises in the Slovenian industry in the observed period is greater than the number of their exits, which means an increase in the number of micro and small enterprises in the Slovenian industry.

This finding applies only to micro enterprises with zero employment, with the exception for the number of newly-established micro-enterprises with zero employment in the year 2015, when the exit of micro-enterprises with zero employment was 3.7\% higher than the number of newly-established enterprises. 
RESTRUCTURING OF THE TEXTILE INDUSTRY

Textile production has been at the heart of European manufacturing production since the start of the industrial revolution. Despite considerable offshoring in lower-cost countries over the last few decades, the European textile sector still accounts for $2.4 \%$ of the $\mathrm{EU}$ manufacturing employment and $1.4 \%$ of the EU production valueadded. They are mostly organized as SMES that are both traditional and modern. These SMEs find it difficult to allocate the finance and human resources needed to evaluate the ability to purchase advanced machines and improve skills required. In addition, some activities in the sector, especially sewing, are difficult to automate. The sector also faces technical barriers to standards for the widespread use of technical textiles and suffers from the loss of traditional skills and difficulties in acquiring new knowledge (European Commission 2015).

THE TEXTILE INDUSTRY IN SLOVENIA

The Slovenian textile industry has been known as a highly laborintensive industry with several smaller enterprises and a more intense market dynamics with the entrances and exits of enterprises. Labor-intensive industries, including the textile industry, exhibited greater dynamics of entry for new micro and small enterprises than exits, resulting in a high concentration of enterprises in the industry, which had an impact on the poorer business results of enterprises and, consequently, later greater dynamics of exit of enterprises in the industry (Bojnec and Xavier 2004; 2005; 2007).

The Number of Enterprises within the Textile Industry (c13, c14,

C15) over the Period 2006-2017

Table 3 shows the number of all registered enterprises within the textile industry (c13, c14, c15), which are obliged to submit annual reports in accordance with the law and to make public the annual reports and other data of enterprises, sole proprietors and other business entities in accordance with Companies Act and Other Laws by the Agency of the Republic of Slovenia for Public Legal Records and Related Services (AJPES).

As can be seen from table 3 the largest share of the textile enterprises was recorded in the activity Manufacture of clothing (c14), with $50 \%$ share of all textile enterprises in Slovenia, followed by the Manufacture of textiles (c13) with 38\% share and Manufacture of leather and leather related products (c15) with $12 \%$ share of all enterprises in the observed period. The largest decrease in the num- 
TABLE 3 The Number of Enterprises within the Departments of Activity in the Textile Sector During the Period 2006-2017

\begin{tabular}{lrrrrrrrrrrrr}
\hline Activity & 2006 & 2007 & 2008 & 2009 & 2010 & 2011 & 2012 & 2013 & 2014 & 2015 & 2016 & 2017 \\
\hline C13 & 218 & 223 & 162 & 158 & 152 & 141 & 143 & 141 & 143 & 146 & 158 & 147 \\
C14 & 252 & 244 & 267 & 232 & 229 & 215 & 202 & 191 & 193 & 186 & 180 & 176 \\
C15 & 68 & 67 & 49 & 47 & 45 & 45 & 44 & 45 & 46 & 46 & 47 & 53 \\
\hline
\end{tabular}

NOTES Column headings are as follows: C13 - Manufacture of textiles/DB17, C14 Manufacture of clothing/Dв18, С15- Manufacture of leather, leather and related articles/Dc. Based on data from AJPEs (see http://www.ajpes.si).

ber of enterprises in the textile sector in the observed period was recorded in the Manufacturing of clothing (c14), followed by a decrease in the number of enterprises in the activity Manufacture of textiles (c13), unlike in the section Manufacture of leather, leather and related departments (c15), which recorded the smallest decline in the number of enterprises over the observed period.

\section{Methodology}

The aim of the research is to determine, by selected analytical methods, how and to what extent the dynamics of reducing the size and age of large and medium-sized textile enterprises affect the entry of new micro and small enterprises into the Slovenian textile industry and the survival of companies in the textile industry business performance indicator. The research is based on data collected by the AJPES in the period from 2006 to 2017, previous professional and scientific literature in the field and use of descriptive and numerical statistical methods. For the analysis and presentation of the survey, the key features of the data are expressed using the descriptive method of statistics. Regression analysis analyzed the relationship between the dependent (explanatory) variable and one or more independent (explanatory) variables.

DATA

The entry and exit rates of the Slovenian textile enterprises are analyzed with company-level data, which include departments of activity: Manufacture of textiles (c13), Manufacture of clothing (c14) and Manufacture of leather, leather and related departments (c15). The data are compiled from the balance sheets of companies obliged by the AJPES to submit annual reports in accordance with the law and to publish publicly the annual reports and other data of enterprises, sole proprietors and other business entities in accordance with Companies and Other Laws for the period 2006-2017 and are part of the $\mathrm{Fi}=$ Po database, which serves as an analytical tool for business re- 
view and in-depth analysis for 2019. The database represents the Slovenian textile industry, including all existing joint-stock companies, limited liability companies, unlimited liability companies, and limited partnerships.

Compared to previous research conducted by Bojnec and Xavier (2004), which covered the entire Slovenian manufacturing industry from 1994 to 2000, the data on the number of enterprises and the number of employees in micro-enterprises, are comparable. The data covered for the period 2006-2017 includes a number of very small textile enterprises. For the entire sample studied during the twelve-year period, the average number of employees in micro Slovenian textile enterprises is 5.6 employees, whereby the majority of enterprises were employing less than 10 employees. The small textile enterprises, which include 336 small textile enterprises on average employ 60 employees.

Therefore, our data is a very accurate picture of the Slovenian textile industry, which allows us to analyze market dynamics with micro and small enterprises, for which according to Mead and Liedholm (1998) there are several factors that would 'influence the patterns dynamics of enterprises.' These factors belong to the enterprises or operators of such enterprises. The practice of identifying and analyzing possible factors in both cases can serve at least two important purposes. First, the practice would help to identify the nature of dynamics of most SMEs and the specific characteristics of those involved in this economic sub-sector. Second, it can help policymakers to design appropriate policy instruments that would then guide government and stakeholders action aimed at effectively supporting and developing the SME sector.

The data are structured by years from 2006 to 2017 inclusive, allowing the entry and exit of textile enterprises to be investigated, and include the following variables: enterprise identification number, registration number of enterprise, enterprise headquarters address, enterprise name, number of employees in the enterprise, form of organizational structure of the enterprise (limited company, limited liability enterprise, unlimited liability enterprise and limited partnership), enterprise assets, enterprise capital, total revenues of the enterprise, net profit or net loss for the enterprise, value-added, value-added per employee and earning before interest, taxes, and depreciation (EBITDA).

\section{CALCULATION OF ENTRY AND EXIT RATES}

We first determine the entry and exit rates used in this article. We define an entrant in section $j$ in period $t$ as an enterprise that is in 
activity in section $j$ in period $t$ but was not in activity in period $t-1$. On the other hand, an enterprise that exits the market in period $t$ is an enterprise that is not in activity in period $t$ in section $j$ but was in activity in that section in the previous period $(t-1)$. We use the enterprise identification number (ID). The rate of entry is calculated by dividing the total number of those enterprises entering section $j$ in period $t$ by the total number of enterprises in section $j$ in period $t-1$. The rate of exit is calculated by dividing the total number of enterprises exiting section $j$ in period $t$ by total number of enterprises in section $j$ in period $t-1$.

Entry and exit rates are calculated as follows:

$$
\begin{gathered}
\text { Entry rate }=\frac{\begin{array}{c}
\text { total number of new (entry) enterprises } \\
\text { in section } j \text { in period } t
\end{array}}{\text { total number of enterprises in section } j \text { in }} \text { period } t-1 \\
\text { Exit rate }=\frac{\text { total number of enterprises that exited in }}{\text { section } j \text { in period } t} \\
\text { total number of enterprises in section } j \text { in } \\
\text { period } t-1
\end{gathered},
$$

where the entry rate is calculated by dividing the total number of those enterprises entering department level $j$ in period $t$ by the total number of enterprises at department level $j$ in period $t-1$ and the exit rate is calculated by dividing the total number of enterprises exiting out from the industry level $j$ in period $t$, divided by the total number of enterprises at department level $j$ in period $t-1$.

As a data source, we use enterprise-level information provided by AJPES for analyzing dynamics of the enterprise, and enterprise size and size structure. This data source represents all enterprises operating in the observed period from 2006 to 2017 by enterprise ID. Therefore, entry and exit rates are calculated based on the enterprise ID, which is used as a criterion to determine if an enterprise has stopped its economic activity (if the ID is no longer in the sample), it has started the economic activity (the ID was not previously in the sample) or is still in economic activity (ID is still in the sample).

CALCULATION OF ENTRY AND EXIT RATES FOR THE SLOVENIAN TEXTILE ENTERPRISES

First, we introduce the entry and exit rates of enterprises in c13, c14 and C15 sections based on the AJPES data for the years 2007 to 2017 . When entering the enterprises in the market, we checked whether 
TABLE 4 Number of Enterprises, Number of Entry and Exit of Enterprises, Entry and Exit Rates of Enterprises, Exit/Entry Dynamics Index, Survival Index and Net Exit/Entry Index of Enterprises in the Sections C13, c14 and c15

\begin{tabular}{lrrrrrrrr}
\hline Year & $(1)$ & $(2)$ & $(3)$ & $(4)$ & $(5)$ & $(6)$ & $(7)$ & $(8)$ \\
\hline 2007 & 534 & 60 & 62 & 11,15 & 11,52 & -0.3 & 99 & 103 \\
2008 & 487 & 103 & 158 & 19,28 & 29,58 & -11.2 & 91 & 153 \\
2009 & 437 & 48 & 89 & 9,85 & 18,27 & -9.3 & 89 & 185 \\
2010 & 426 & 58 & 69 & 13,27 & 15,78 & -2.5 & 97 & 118 \\
2011 & 401 & 42 & 66 & 9,85 & 15,49 & -5.9 & 94 & 157 \\
2012 & 389 & 47 & 60 & 11,72 & 14,96 & -3.3 & 97 & 127 \\
2013 & 377 & 38 & 49 & 9,76 & 12,59 & -0.2 & 96 & 127 \\
2014 & 382 & 44 & 40 & 11,67 & 10,61 & 1.0 & 101 & 90 \\
2015 & 378 & 41 & 45 & 10,73 & 11,78 & -1.0 & 98 & 109 \\
2016 & 385 & 50 & 45 & 13,22 & 11,90 & 1.2 & 101 & 90 \\
2017 & 376 & 65 & 67 & 16,88 & 17,40 & -0.5 & 97 & 103 \\
\hline
\end{tabular}

Notes Column headings are as follows: (1) number of enterprises, (2) entry of enterprises, (3) exit of enterprises, (4) entry rate, (5) exit rate, (6) net entry/exit rate, (7) survival index, (8) net exit/entry index.

the enterprises that had been on the Slovenian market for the selected year existed on the same market already the year before. If the enterprises did not exist on the market a year earlier, those enterprises entered the market that year. The rate of entry of enterprises into the market is calculated as the ratio between the number of new (entering) enterprises and the number of all enterprises on the market in the previous observed year. At the exit of enterprises from the market, we checked whether the enterprises that were in the selected year on the Slovenian market in that market in also the following year. If the enterprises did not exist on the market in the following year, these enterprises have exited the market. The rate of exit of enterprises from the market is calculated as the ratio between the number of exiting enterprises from the market and the number of all enterprises on the market in the previous observed year.

Table 4 presents entries and exits of enterprises in the Slovenian textile industry in sections C13, c14 and c15. Net entry/exit rate of Slovenian textile enterprises is calculated as the difference between the entry and exit rates, which represents the difference between the number of new (entrances) enterprises and the number of exit enterprises in the observed year and the number of all enterprises in the observed year. The negative sign of the net entry/exit rate tells us that in a given year more companies left the market than they entered the market. 
TABLE 5 Correlation Matrix between Three Pairs of Variables: The Entry Dynamics of Micro and Small Enterprises (ST_VSP), the Number of Medium and Large Enterprises (v_vsP), and the Survival Rate of Medium and Large Enterprises (v_MM)

\begin{tabular}{llrrr}
\hline Item & & ST_VSP & P_VSP & V_MM \\
\hline Pearson correlation & ST_VSP & 1.000 & -0.458 & 0.097 \\
coefficient & P_VSP & -0.458 & 1.000 & -0.441 \\
& V_MM & 0.097 & -0.441 & 1.000 \\
\hline Significance (1-tailed) & ST_VSP & - & 0.078 & 0.388 \\
& P_VSP & 0.078 & - & 0.047 \\
& V_MM & 0.388 & 0.047 & - \\
\hline$N$ & ST_VSP & 12 & 11 & 11 \\
& P_VSP & 11 & 11 & 11 \\
& V_MM & 11 & 11 & 11 \\
\hline
\end{tabular}

Notes Based on data from AJPes (see http://www.ajpes.si).

\section{REGRESSION MODEL FOR HYPOTHESIS TESTING}

The set two hypotheses are tested using correlation and regression analyses.

HYPотHESIS 1 For the purpose of testing the set hypothesis 1, the correlation and regression analyses are applied. Data were used for the entry rates of micro and small enterprises in the textile industry, the number of large and medium-sized enterprises in the textile industry, the survival rate of large and medium-sized textile enterprises, in the observed period from 2006 to 2017, in sections manufacture of textiles (c13), manufacture of clothing (c14) and manufacture of leather, leather and related articles (c15).

The Pearson correlation coefficient shows that the association between the V_MM and P_vsP variables is -0.441 , which means that a negative linear association between the variables exists and is medium to moderate (table 5). In the given case, there is a medium to the moderate negative correlation between the two variables. Statistical significance (Sig. 0.047) is less than 0.05, which means that statistical significance exists. We can conclude that the entry of micro and small textile enterprises into the market is related to the survival of large and medium-sized textile enterprises. The Pearson correlation coefficient between V_MM and ST_VSP variables is 0.097 , indicating a slight positive association between the variables. The statistical significance (Sig. 0.388) is greater than 0.05, which means that the correlation between the variables is not statistically significant. 
TABLE 6 Model Summary

\begin{tabular}{|c|c|c|c|c|c|}
\hline$R$ & $R^{2}$ & Adjusted $R^{2}$ & \multicolumn{3}{|c|}{ Standard error of the estimate } \\
\hline $0.457^{*}$ & 0.209 & 0.011 & \multicolumn{2}{|c|}{3.13159} & \\
\hline \multicolumn{6}{|c|}{$\begin{array}{l}\text { NOTES }{ }^{*} \text { Predictors: (constant), survival rate of large and medium-sized textile en- } \\
\text { terprises (P_VSP), and the number of large and medium-sized textile enterprises } \\
\text { (ST_VSP). }\end{array}$} \\
\hline \multicolumn{6}{|c|}{ TABLE 7 Anova } \\
\hline Item & Sum of squares & DF Mean & square & $F$ & Sig, \\
\hline Regression & 20.668 & 2 & 10.334 & 1.054 & $0.392^{*}$ \\
\hline Residual & 78.455 & 8 & 9.807 & & \\
\hline Total & 99.123 & 10 & & & \\
\hline
\end{tabular}

Notes * Predictors: (constant), survival rate of large and medium-sized textile enterprises (P_VSP), and the number of large and medium-sized textile enterprises (ST_VSP). Dependent variable: entry rates of micro and small textile enterprise (v_MM)

The multiple correlation coefficient is 0.457 , indicating that the correlation between the independent variables and the dependent variable (entry of micro and small enterprises in the textile industry) is modest (table 6). The value of the multiple coefficient of determination is 0.209 , indicating a weak explanation of the dependent variable with the independent variables in the regression model. The independent variables statistically significantly explain 21 percent of the variance of the entry of micro and small textile enterprises into the industry.

Table 8 present the estimated regression coefficients with the $t$ test value and the risk level. The results of the regression analysis indicate that the number of large and medium-sized textile enterprises and the survival rate of large and medium-sized textile enterprises have no statistically significant effect on the entry rate of micro and small textile enterprises. Therefore, the null hypothesis $\mathrm{H} 1$ that the entry rate of micro nad small textile enterprises increases with decreases in the number and survival rate of the existing large and medium-sized textile enterprises can be rejected.

TABLE 8 Regression Coefficient

\begin{tabular}{lrrrrr}
\hline Item & $B$ & Std. error & Beta & $T$ & Sig. \\
\hline (Constant) & 32.017 & 15.505 & & 2.065 & 0.073 \\
ST_vSP & -0.041 & 0.110 & -0.133 & -0.377 & 0.716 \\
P_vSP & -20.676 & 14.574 & -0.502 & -1.419 & 0.194 \\
\hline
\end{tabular}

Notes *Dependent Variable: entry rates of micro and small textile enterprise (V_MM) 
TABLE 9 Correlation matrix between three pairs of variables: dynamics of the exited of large and medium-sized enterprises (I_VSP), value-added per employee in large and medium-sized enterprises (DVZ_VsP), and profit before taxes, interest on loans, excluding depreciation in large and medium-sized enterprises (EBI_VSP)

\begin{tabular}{llrrr}
\hline Item & & ST_VSP & P_VSP & V_MM \\
\hline Pearson correlation & I_VSP & 1.000 & -0.421 & 0.417 \\
coefficient & EBI_VSP & -0.421 & 1.000 & 0.398 \\
& DVZ_VSP & 0.417 & 0.398 & 1.000 \\
\hline Significance (1-tailed) & I_VSP & - & 0.099 & 0.101 \\
& EBI_VSP & 0.099 & - & 0.100 \\
& DVZ_VSP & 0.101 & 0.100 & - \\
\hline$N$ & I_VSP & 11 & 11 & 11 \\
& EBI_VSP & 11 & 12 & 12 \\
& DVZ_VSP & 11 & 12 & 12 \\
\hline
\end{tabular}

NOtes Based on data from AJPes (see http://www.ajpes.si).

TABLE 10 Model Summary

\begin{tabular}{llll}
\hline$R$ & $R^{2}$ & Adjusted $R^{2}$ & Standard error of the estimate \\
\hline o.757* & 0.573 & 0.467 & 0.63379 \\
\hline NOTES & ${ }^{*}$ Predictors: (constant), survival rate of large and medium-sized textile en- \\
terprises & (P_VSP), and the number of large and medium-sized textile enterprises \\
(ST_VSP).
\end{tabular}

нуротнеSIS 2 To test the set hypothesis 2 using the correlation and regression analyses, we used the data on the exit rate of large and medium-sized textile enterprises, average value added per employee and average pre-tax profit, interest on loans, excluding depreciation (Е ВITDA) in large and medium-sized textile enterprises in each year, in the observed period from the year 2006 to 2017, in the $\mathrm{c} 13$ (textile production), c14 (clothing production) and c15 (leather, leather and related products) section.

The Pearson correlation coefficient between the variables I_vsP and EBI_VSP variables is -0.421, indicating that the association between the variables is negative, medium to moderately strong. The level of significance (Sig. 0.099) is greater than 0.05, which means that the variables are not statistically correlated (table 9). The Pearson correlation coefficient between the variables I_VSP and DVZ_VSP is 0.417 , indicating a positive, medium to moderate correlation. The significance level is less than 0.05, (Sig. 0.101), which means that no statistical significance exists.

The multiple correlation coefficient is 0.757 , indicating that there 
TABLE 11 Anova

\begin{tabular}{lrrrrr}
\hline Item & Sum of squares & \multicolumn{1}{c}{ DF } & Mean square & $F$ & Sig, \\
\hline Regression & 4.318 & 2 & 2.159 & 5.375 & $0^{*} 033^{*}$ \\
Residual & 3.213 & 8 & 0.402 & & \\
Total & 7.531 & 10 & & & \\
\hline
\end{tabular}

Notes * Predictors: (constant), survival rate of large and medium-sized textile enterprises (P_VSP), and the number of large and medium-sized textile enterprises (ST_VSP). Dependent variable: entry rates of micro and small textile enterprise (V_MM)

TABLE 12 Regression Coefficient

\begin{tabular}{lrrrrr}
\hline Item & $B$ & Std. error & Beta & $T$ & Sig. \\
\hline (Constant) & 1.088 & 0.736 & & 1.478 & 0.178 \\
EBI_VSP & -0.928 & 0.339 & -0.685 & -2.735 & 0.026 \\
DVZ_VSP & 0.057 & 0.021 & 0.683 & 2.726 & 0.026 \\
\hline
\end{tabular}

Notes *Dependent Variable: entry rates of micro and small textile enterprise (

is a good correlation between the independent variables and the dependent variable (table 10). The value of the multiple coefficient of determination is 0.573 , which indicates that the independent variables statistically significantly explain 57.3 percent of the variance in the exited of large and medium-sized textile enterprises in the textile industry. The $F$-test value is 5.375 . Significance level (Sig.) is 0.033, which is less than $\alpha=0.05$. Therefore, it is statistically significant. Based on this, we conclude that the model has at least one statistically significant variable.

The regression model showed that the $t$-test value for both independent variables (value-added per employee in large and mediumsized textile enterprises and business performance of the enterprise) is less than the risk level $\alpha=0.05$, so we can conclude that the variables have statistically significant influences the exit rate of large and medium-sized enterprises in the textile industry in Slovenia (table 12). However, the sign of the regression coefficient pertained to the variables DVz_vsP is positive suggesting that higher valueadded per employee increased the exit of the large and mediumsized enterprise. Therefore, the set hypothesis $\mathrm{H} 2$ can be rejected in this part.

\section{Empirical Findings and Discussion}

The survey showed that the number of large and medium-sized Slovenian textile enterprises decreased by about 70 percent over the observed period; the largest decrease in the number of large and 
medium-sized textile enterprises was in the year 2009, by 34 percent compared to the base year 2006.

The results of the research show that the dynamics of newly established textile enterprises was highest in 2008. In the same year the dynamics of exit of enterprises from the market, was 35 percent higher than the dynamics of newly established textile enterprises in the industry, which was expected given the period of instability of the Slovenian economy and the general economic crisis.

The research found that the entry rate of textile enterprises was on average 3 percent higher than the exit rate of textile enterprises from the market in the observed period 2006 to 2017. In the year 2008 , the entry rate of the textile enterprises was less than the exit rates of the textile enterprises by 10.3 percent, which is attributable to the unfavourable economic conditions and the large fluctuations in macroeconomic indicators. The smallest fluctuation in the difference between the rate of entry and the rate of exit of enterprises from the market was detected between 2014 and 2016; that is, in a time of favourable economic conditions and stability of the Slovenian economy. The results of the research show that the highest survival rate of the Slovenian textile enterprises was 1.2 percent in 2016, while was the lowest survival rate for textile enterprises was 0.89 percent in 2009.

The results of the correlation analysis show that there is a negative moderate relationship between the survival of large and mediumsized textile enterprises and the number of micro and small enterprises entering the textile industry. The results of the regression analysis show that the entry of micro and small textile enterprises into the industry is related to the survival of large and medium-sized textile enterprises. Based on the results of the regression analysis, we can conclude that the increased entry of micro and small textile enterprises into the market is reducing the survival of large and medium-sized textile enterprises. The exit rate of large and mediumsized enterprises in the textile industry decreases if the business performance of large and medium-sized enterprises in the textile industry increases. However, the level of exit rate of the large and medium-sized enterprises in the textile industry increases as the value-added per employee in the large and medium-sized textile enterprises increases, which is inconsistent with the set hypothesis 2 .

\section{Conclusion}

The dynamics of entry of micro and small textile enterprises into the market has not been driven by the restructuring and reduction of the 
number and rate of survival of medium and large textile enterprises.

The increased dynamics of exit of large and medium-sized textile enterprises is conditioned by the business failure of managing large and medium-sized textile enterprises. Value-added per employee did not reduce the exit of medium and large textile enterprise over the observed period. Value-added per employee increased, due to the reduction in the number of employees in textile enterprises as a result of the restructuring of the Slovenian textile industry. The research shows that favourable economic conditions and stability of the Slovenian economy affect the dynamics of entry and exit of enterprises from the market.

The conducted research has an important contribution to the literature, and especially to experts who are professionally active in the field of the textile industry and who will find useful information for a better understanding of the causes and consequences of restructuring of the Slovenian textile industry. In particular, business managers should acknowledge the benefits of the survey findings. The continued impetus in this direction may also represent the present insight into the relationship between the level of development of the Slovenian textile industry and the business performance of enterprises.

The research has many limitations. The first limitation is the fact that the measurement of the dynamics of enterprises in the Slovenian textile industry was based on a limited sample of enterprises in the textile industry. The following restriction refers to the limited period from the year 2006 to 2017, given that the restructuring of the Slovenian textile industry began earlier in the year 1989 and following the Slovenian independence in 1991 during the greatest depression, mainly due to the loss of the former Yugoslav markets. An additional limitation was the fact that the seemingly successful rescue of large Slovenian textile enterprises, which received government subsidies for rescue and restructuring, mainly to alleviate social problems and tensions, and as such enterprises existed on the market 'artificially,' which is already the subject of further research.

\section{References}

Audretsch, D. B. 1991. 'New-Firm Survival and the Technological Regime.' The Review of Economics and Statistics 73 (3): 441-50.

- 1995. 'Innovation, Growth and Survival.' International Journal of Industrial Organization 13 (4): 441-57.

Birch, D. L. 1979. 'The Job Creation Process.' Unpublished report, MIT Program on Neighbourhood and Regional Change. 
Bojnec, Š., and A. Xavier. 2004. 'Entry and Exit in Transition Economies: The Case of the Slovenian Manufacturing Sector.' Post-Communist Economies 16 (2): 191-214.

- 2005. 'Firm and Labour Dynamics in Slovenian Manufacturing.' Društvena istraživanja 1 (6): 1103-27.

- 2007. 'Determinants of Firm Exit in the Slovenian Manufacturing.' Industrial Management \& Data Systems 107 (5): 715-27.

Carlsson, B. 1999. 'Small Business, Enterpreneurship, and Industrial Dynamic.' In Are Small Firms Important? Edited by Z. Acs, 99-110. Dordrecht: Kluwer Academic Publishers.

Cincera, M., and O. Galgau. 2005. 'Impact of Market Entry and Exit on EU Productivity and Grow Performance.' Economic Papers 222, The Directorate-General for Economic and Financial Affairs, Brussels.

Dunne, T., M. J. Roberts, and L. Samuelson. 1989. 'The Growth and Failure of U.S. Manufacturing Plants.' Quarterly Journal of Economics 104 (4): 671-98.

European Commission. 2005. 'Impact of Market Entry and Exit on EU Productivity and Growth Performance.' https://ec.europa.eu/ economy_finance/publications/pages/publication712_en.pdf

- 2015. The Annual Report 2015. Luxemburg: Publications Office of the European Union.

- 2019. The Annual Report 2018. Luxemburg: Publications Office of the European Union.

Félix, S. 2017. 'Firm Creation and Survival in Portugal.' Economic Bulletin and Financial Stability Report Articles and Banco de Portugal Economic Studies, Banco de Portugal, Economics and Research Department, Lisbon.

Geroski, P. A. 1995. 'What Do We Know about Entry?' International Journal of Industrial Organization 13 (4): 421-40.

Geroski, P. A., J. Mata, and P. Portugal. 2003. 'Founding Conditions and the Survival of New Firms.' Banco De Portugal, Economic Research Department, Lisbon.

Ghosal, V. 2003. 'Impact of Uncertainty and Sunk Costs on Firm Survival and Industry Dynamics.' cic Working Papers SP II 2003-12, Wissenschaftszentrum Berlin, Berlin.

Haltiwanger, J., R. S. Jarmin, and J. Miranda. 2013. 'Who Creates Jobs? Small versus Large versus Young.' Review of Economics and Statistics 95 (2): 347-61.

Jelili, R. B., and M. Goaied. 2009. 'Entry, Exit, Resource Reallocation and Productivity Growth in the Tunisian Private Manufacturing Industries.' Working Papers 477, Economic Research Forum, Cairo.

Kaya, S., and Y. Üçdoğruk. 2002. 'The Dynamics of Entry and Exit in Turkish Manufacturing Industry.' E RC Working Papers in Economics 02/o2, Middle East Technical University, Ankara. 
Kocjančič, J., and Š. Bojnec. 2010. 'Firms Dynamics and the Shadow Economy in the Wood Industry in Slovenia.' International Journal of Sustainable Economy 2 (2): 194-209.

Mead, D. C., and C. Liedholm. 1998. 'The Dynamics of Micro and Small Enterprises in Developing Countries.' World Development 26 (1): 6174 .

Rebernik, M., P. Tominc, and K. Pušnik. 2006. Podjetništvo med željami v resnici: Global Entrepreneurship Monitor Slovenija 2005. Maribor: Ekonomsko-poslovna fakulteta, Inštitut za podjetništvo v velikih podjetjih, Univerza v Mariboru.

Scarpetta, S., P. Hemmings, T. Tressel, and J. Woo. 2002. 'The Role of Policy and Institutions for Productivity and Firm Dynamics: Evidence from Micro and Industry Data.' oEcD Economics Department Working Papers 329, OECD, Paris.

Sönmez, A. 2013. 'Firm Entry, Survival, and Exit.' Academic Journal of Interdisciplinary Studies 2 (9): 160-68.

This paper is published under the terms of the Attribution-

NonCommercial-NoDerivatives 4.o International (CC BY-NC-ND 4.0)

License (http://creativecommons.org/licenses/by-nc-nd/4.o/). 